\title{
Information and Communication Technologies in Pre-school Settings: a review of the literature
}

\author{
Christine Stephen and Lydia Plowman
}

\begin{abstract}
This article reviews the research evidence that relates to the use of Information and Communication Technologies (ICT) in pre-school settings. While there is widespread agreement that children should be helped to become confident users of ICT the literature presents a more qualified picture of potential benefits and barriers. The review considers the polarised debate about whether computer use is desirable for young children; the position of ICT as one element in the multi-media mix experienced by children; evidence available about current ICT provision and practice in pre-school settings in the UK and perspectives on the contribution that ICT makes to learning. The need for adults and children to acquire ICT literacy skills is identified, along with a requirement that practitioners should be equipped to make appropriate resource choices. The way in which ICT can play a compensatory and engaging role or further entrench disadvantage ('the digital divide') is discussed. The review concludes that the pedagogical imperative must remain with practitioners.
\end{abstract}

\section{Sommaire}

Cet article passe en revue la documentation de recherche relative à l'emploi des technologies d'informatique et de communication (TIC) dans le cadre de l'apprentissage préscolaire. Si l'opinion est largement répandue qu'il faille aider les enfants à se familiariser avec les TIC, les articles de recherche sur ce sujet présentent une image plus conditionnelle concernant les avantages potentiels et les divisions éventuelles que ces technologies peuvent amener. La revue envisage le débat polarisé de savoir si l'emploi de l'ordinateur est souhaitable pour les enfants en bas âge; la position des TIC en tant qu'élémnet parmi la gamme des média auxquels les enfants sont exposés; la documentation existante concernant la disponibilité et les applications pratiques dans le cadre préscolaire au Royaume-Uni et les perspectives sur la contribution apporté par les TIC dans le domaine de l'apprentissage. Le besoin qu'ont les adultes et les enfants d'acquérir une solide compétence est identifié ainsi que la nécessité qu'ont les enseignants d'avoir la formation nécessaire afin d'être à même de faire un choix de ressources approprié. Comment les TIC peuvent jouer un rôle compensatoire et engageant ou au contraire accentuer le désavantage (la défavorisation digitale) fait l'objet d'une discussion. La revue conclut que l'impératif pédagogique doit rester aux mains des enseignants.

\section{Sumario:}

Este artículo examina los resultados de las investigaciones realizadas sobre el uso de las Tecnologías de Información y Comunicación (TIC) en marcos preescolares. Mientras que existe un acuerdo general en que se debería ayudar a los niños a que gradualmente vayan adquiriendo soltura y confianza en el uso de las TIC, el material publicado nos ofrece una perspectiva más cualificada de los beneficios así como de las barreras con las que potencialmente pueden encontrarse. Este estudio examina el debate polarizado sobre si el uso de ordenadores por parte de niños pequeños es o no 
deseable; la posición de las TIC como un elemento multimedia más de los experimentados por el niño; las pruebas disponibles sobre el abastecimiento y práctica actual de las TIC en marcos preescolares en el Reino Unido y las perspectivas sobre la contribución de las TIC al aprendizaje. Se identifica la necesidad de que tanto adultos como niños estén instruidos en las TIC, junto con el requisito de que los profesionales deberían estar equipados para tomar las elecciones apropiadas con respecto a los recursos. Se discute la manera en la que las TIC pueden jugar un papel compensatorio y atractivo, o pueden consolidar más una posición desventajosa ('la división digital'). El estudio concluye que el imperativo pedagógico debe permanecer con los profesionales.

\section{Introduction}

A look at the literature on Information and Communication Technologies (ICT) and at policy developments in educational provision across the UK quickly reveals that ICT is highly placed among the priorities that policy makers and parents have for education. There is a widespread belief among educators and parents that children will require technological competencies to succeed in the workplace. Furthermore, the political commitment to creating the conditions considered necessary to develop a 'knowledge economy' has given rise in the school sector to such initiatives as The National Grid for Learning and ICT training for new and established teachers.

Although the pre-school curriculum guidelines in Scotland (Curriculum Framework for Children 3 to 5 (SCCC, 1999)) do not make any specific reference to ICT, informal observation of playrooms in the voluntary, private and public sectors suggests that computers are commonly present. The National Curriculum for England (2000) has explicit aims for ICT skills at Key Stage 1 (children aged 5-7 years), that is, that children should use ICT confidently and purposefully and be starting to use it to develop their ideas and record their creative work. Children in reception classes and nurseries are expected to be 'working towards' Key Stage 1. In the USA in 1996 the National Association for the Education of Young Children (NAEYC) adopted a position statement on Technology and Young Children (3-8). This statement endorsed the use of developmentally appropriate software for collaborative play, learning and creation.

However, this confidence in the importance of ICT does not go unchallenged. Cuban (2001) claims that it is belief, not research evidence, which drives investment in computers for pre-school. Mioiduser, Tur-Kaspa and Leitner (2000) refer to the presence of technology in early childhood education as 'hardware reality' that has not yet become a technology-based learning reality. They go on to suggest that 'first hardware-based enthusiasm, then pedagogical reflection' is a recurrent pattern in the adoption of new technologies in education.

Before presenting the literature examined it is necessary to sound a note of caution about the scarcity of good quality research findings on using ICT in educational settings for pre-school children. There is a proliferation of reports, articles and web sites that make claims for the benefits to be derived from children using computers but the evidence base for much of this writing is weak and some of the claims rely on assertion rather than empirical study. Many articles are characterised by generalised 
discussion of the potential benefits, followed by cautions to use developmentally appropriate software and guidance about how to choose such software or how to begin using computers in the playroom (e.g. Haugen, 1998; Yelland, undated). Furthermore, much of the evidence that is available relates to school-aged children rather than the 3-and 4-year olds that attend pre-school educational settings in the UK.

Our review (commissioned by Learning and Teaching Scotland) begins with the debate at the heart of discussions about ICT use in pre-school settings, that is, is computer use desirable or beneficial for young children? Secondly, we consider ICT as part of the multi-media mix that children experience; the demands that that places on our understanding of multi-media literacy and the need to make informed choices among the equipment and products available. We move on to an examination of the evidence available on current ICT provision and practice in pre-school provision in the UK. Finally, we review the literature that focuses on the contribution that ICT makes to young children's learning across curricular areas.

\section{Should Young Children Use ICT?}

At its extremes, the debate has become polarised between those who consider computers to be detrimental to health and learning and those for whom computers can make a key contribution to children's social and intellectual development. So far, the debate has found strongest expression in the United States and the conservative view is exemplified by the Alliance for Childhood's stance. Fool's Gold: A Critical Look at Computers in Childhood (2000) calls for an immediate moratorium on the further introduction of computers in early childhood, except for special cases of students with disabilities. It also recommends a refocusing on 'the essentials of a healthy childhood', such as play, reading books and 'hands-on experiences of nature and the physical world'.

In the UK, Buckingham (2000) characterises this position as adopting the 'death of childhood' thesis, which is fuelled by a combination of panic and nostalgia. This position is opposed by those who believe that children are empowered by the new media, that ICT can be used creatively and is central to their enculturation into the knowledge society and economy. However, opponents argue that such an approach risks positioning children as consumers and blurs the distinctions between work and play.

The main concerns centre on protection issues such as online privacy, children's understanding of the commercial intentions of many websites and the risk of exposure to unsuitable content of either a sexual or violent nature. Other concerns focus on the physical effects of prolonged exposure to ICT, such as repetitive strain injuries, addiction and sedentary lifestyles. The BECTA information leaflet (2001) on keyboard skills in schools states that for children with years of typing ahead of them, using the keyboard with index fingers only is highly risky, especially when there may be added strain from playing games on home computers. Research on the possible addictive nature of the Internet and computer games has so far been limited to older children. 
Underlying educational concerns is the belief that computers may damage young children's development. Healy (1998), for instance, claims that using computers before the age of seven 'subtracts from important developmental tasks'. Cuban (2001) notes that early childhood researchers and policymakers habitually cite brain research on infants and young children to support or rebut positions on the 'critical period' of intellectual development but most neuroscientists are reluctant to apply their findings to pre-school settings.

The predominant view among those who are critical of ICT use in pre-school is that, as a screen-based medium, activities at the computer are not as effective as manipulative or concrete activities in developing understanding and skills in the early years (Yelland, 1999) and that, as children learn through their bodies, computers are not developmentally appropriate (Haughland, 2000). These concerns are predicated on the use of desktop computers and have less currency as ICT becomes embedded in a range of everyday objects and uses wireless technologies, as described below.

This unresolved debate is evident in the views of parents as well as practitioners and 'experts' as two studies revealed. Surveys by the US National School Boards Foundation (NSBF, 2000) and the Annenberg Public Policy Centre (Turow and Nir, 2000) found that parents were broadly supportive of the Internet as a valuable educational resource but worried about children encountering pornography, violent content or being enticed to disclose information to commercial interests.

\section{ICT in a Multi-media Context}

\section{Multi-media literacy}

Children's ICT experiences in early years settings are only part of the wider media environment that they are exposed too. In this wider media environment the boundaries are being eroded. For example, television programmes have websites and invite children to communicate using e-mail or text messages. Furthermore children's media experiences at home may be very different from their experiences in the nursery. The results of one study (Marsh and Thomson, 2001) suggest that at home 3and 4-year olds watched television far more often than they played computer games. In contrast in their pre-school setting they are more likely to be encouraged to use a computer than to watch television. The mix of media that children are exposed to and the blurring of distinctions between media forms suggests that children need support to develop media awareness and an appreciation of different genre and uses, just as they do with print media.

Engagement with ICT also demands familiarity with a new literacy, that is, the processes by which we create and share meanings with and through ICT (Turbill, 2001; Yelland, 1999). It cannot be assumed that 'reading' or taking meaning from ICT mediated sources involves the same skills as those used with print media. Practitioners need opportunities to acquire screen literacy and navigation skills that they can share with children, as they do book knowledge and language. Becoming ICT literate includes learning to navigate the text, understanding the structure of multi-media documents, locating and retrieving information and understanding the meaning of icons and the conventions of the computer screen (Plowman, 1998). If developing ICT literacy is part of the learning opportunities offered in pre-school 
settings then children's growing facility should be observed and recorded just as emerging print literacy is monitored. Information about children's ICT literacy could be included in the information passed on to schools too.

\section{ICT resources and choices}

Desk-top computers with a visual screen are not the only form of computer available. There is a growing array of products aimed at younger children that do not rely on a visual display, keyboard or mouse. Instead, these products exhibit a range of interface modalities: they can be haptic (sensitive to touch), manipulative (three-dimensional) (Resnick et al., 1998) or anthropomorphic in the sense of simulating human characteristics such as movement or emotion (Strommen \& Alexander, 1999). These toys are not tethered by cables in the same way as personal computers and so are portable. They can be wearable or cuddly and range from soft toys that communicate with the computer by radio transmitter to robotic pets. Interactive books such as LeapPad are, like traditional books, picture and text-based and freestanding but with the addition of audio and stylus input. There is also an expanding market for increasingly communicative digital toys, including dolls that 'learn' to walk and exhibit a range of emotions.

The quality of the design of these products is likely to make a crucial contribution to their effectiveness but the domestic market, rather than the educational market, drives design. Similarly, software designed for the domestic market often has higher production values but will not necessarily have been designed on pedagogic principles. Playroom practitioners need opportunities to learn about the advantages and disadvantages offered by different design features, advice about software choices and familiarity with the criteria that can guide choice. Unfortunately it may be necessary to try out software to reveal its potential flaws and usefulness. All educational software has an implicit model of learning and teaching inherent in the programme but this is seldom explicit and staff will want to discover if a new product matches their preferred model of teaching and learning. There are complex rating scales that try to guide choice but the evaluation criteria they use is not always made explicit and in reducing an array of categories to a simple score they can lose utility. For instance, the Haugland/Shade Developmental Software Scale (Haugland and Wright, 1997) reduces 40 categories to a score out of 10.

\section{ICT Provision and Practice in Pre-school Settings}

\section{The perspectives of practitioners}

Although observation suggests that a computer is commonly available for use during free play (particularly in the public sector settings) a search for survey evidence about the provision of computers or programmable toys in pre-school settings in Scotland (or elsewhere in the UK) revealed no statistical evidence about current usage or playroom availability. This is perhaps not surprising, given the very diverse nature of pre-school provision and the under-developed state of research in the area. However, if a deficit model of training for practitioners (emphasising staff inadequacies in relation to some external model of good practice) is to be avoided it is necessary to consider where children and adults are now as ICT users. 
The literature suggests that parents are likely to be more enthusiastic about ICT than educators, perhaps because some practitioners are still ambivalent about the value of ICT for their practice. Research evidence suggests that there may be some resistance to ICT from teachers and organisations (Turbill, 2001). Haugland (1999) contrasts parents' enthusiastic endorsement of classroom computers use with the situation of teachers who are still struggling with questions about the value of ICT and their own role in a computer integrated classroom.

A study of the current use of ICT by teachers in Scottish schools (Williams et al, 2000) suggested that two-thirds of primary teachers felt competent or very competent with ICT in classroom practice but were much less confident about using ICT out of lessons. In contrast, recent evidence from case studies of Scottish primary schools (Plowman, forthcoming) found that although not all of the teachers used ICT in lessons, they all used ICT for preparation, administration or to develop their own ICT skills. It is not possible to extrapolate confidently from these school-based studies, particularly as staff in nursery schools, nursery classes and playgroups have diverse educational and training backgrounds. However, it does seem safe to suggest that there will be pre-school staff with perspectives on using ICT that range from the 'doubters' identified by Haugland to those who are confident about supporting children using ICT in the playroom and those who happily use computers for personal use but are less confident when working with others. An intervention programme which placed computers and specific software in 14 nurseries in England and Scotland (Siraj-Blatchford J \& I, 2001) found that many practitioners felt some discomfort initially when the computers were installed but gained confidence, with over 60 percent feeling comfortable over time (replicating results obtained in a parallel study in USA).

While we searched for evidence about the way in which practitioners could use ICT to develop their practice and facilitate administration, only two sources made explicit reference to this. Liang and Johnson (1999) describe ICT as a 'wonderful tool' for formative assessment, offering ways to store artefacts, pictures and narratives and Wright (2001) refers to ICT as having uses in professional development, lesson planning and for partnership work with parents.

It seems clear that any development programme offered to pre-school practitioners will have to address the needs of all staff if it is to avoid ICT being seen as the responsibility of one or two confident users or the centre manager. Williams et al suggest that, in addition to appropriate training (in terms of skills, knowledge, relevance to educational goals and priorities) staff need ready access to ICT resources and ongoing support and advice to encourage progression beyond any formal training. The forthcoming study by Plowman notes that three-quarters of teachers consider they do not have enough technical support and nearly three-quarters of primary school teachers have 'sometimes' or 'frequently' had to abandon or alter a lesson plan due to technical problems.

\section{Children's use of ICT}

Observations of the experience of 3- and 4-year olds in all-day provision in eight case study settings in Scotland suggested that, while a computer was available in most (though not all) of the playrooms, this was not an activity 'frequently engaged' in any 
setting (Stephen et al, 2001). Available as a free choice, rather than as an adult-led activity, computers were one of many options competing for children's attention. The intervention study mentioned above reported that practitioners estimated that the equipment was used between 50 and 90 percent of the time for which it was available but that they had varying views about how much of this was 'productive' use. A study of eleven pre-school settings in Silicon Valley (Cuban, 2001) found that all but two of the kindergarten teachers offered computer activities as a free choice activity (two teachers used the computer in an interactive whole group teaching activity). Typically the children were neither obliged to use the computer nor to produce any particular piece of work there. The computer was adopted as another 'centre' in the playroom, incorporated into the existing playroom practice rather than revolutionising practice. Cuban ( $\mathrm{p} 59$ ) goes on to argue that

All of the teachers...except for those two, saw using computers as no more important a learning activity than playing with blocks and Lego... [T] teachers' limited use of computers signalled ambivalence, even uncertainty, over the proper uses of technology for children.

Selwyn and Bullon (2000) found that younger primary school children tended to express unconditional preference for using the computer, regardless of the activity, while older children were more discriminating. They also point out that not all children will react the same way to opportunities to engage with technology and Yost (1998, cited in Liang and Johnson, 1999) found that only four out of eight kindergarten children were drawn to the multimedia centre.

\section{Equal access and ICT as an inclusive resource}

Concerns about equitable access apply to ICT as to any other learning opportunity offered in the playroom. While there may be no evidence of gender differences in ICT use in the playroom (Selwyn and Bullon, 2000; Shade, 1996; Haughland, 1992) and there is no literature on ethnicity there is a body of evidence to suggest that there are inequalities that arise from socio-economic differences between families and home access to a computer.

This 'digital divide' mirrors other socio-economic divides in society. Haugland (2000) quotes a study in the USA which found that eighty percent of children in households with an income of $\$ 75,000$ or more had access to a computer at home while only twenty percent of children living in households with an income of less than $\$ 30,000$ had a home computer. In 2000, the Scottish Household Survey reported that $54 \%$ of households with an annual income over $£ 20,000$ had access to the Internet from home compared to $9 \%$ of households with an income of less than $£ 10,000$. Cuban (2001) concluded that having a computer at home added considerably to a child's competence and confidence with basic computer skills. Selwyn and Bullon (2000) suggest that, for many children, use of ICT in school is secondary to their engagement with technology outside formal education and that access to ICT at home forms a distinctive part of children's 'cultural capital'. Such evidence suggests that pre-school practitioners should be aware of children's home use of ICT and offer an introduction to the playroom ICT resources that is tailored to individual needs and experience. 
In contrast to this discussion on inequalities arising from experience of ICT there is some evidence that technology can have a compensatory role by offering specific assistance to children from disadvantaged backgrounds. An early study by Cohen (1993) suggested that the use of a voice synthesiser to augment specialised software contributed to 'impressive learning results and social development' among 3- to 6year old immigrant children learning French as a second language. Talley, Lancy and Lee (1997) offered opportunities to use CD-ROM storybooks to four-year-olds enrolled in a Head Start programme. Their results suggest that CD-ROM storybooks are a useful resource for increasing exposure to books and print (the storybook culture) for children who are not 'well-read-to' at home. A study in the UK (Nicolson, Fawcett and Nicolson, 2000) reported that computer-assisted reading support can help children (6- and 8-year-olds) at risk of reading failure. Similarly an Australian study (Elliott and Hall, 1997) demonstrated that computer-based, teacherguided activities were an effective resource for pre-school children enrolled in a mathematics early intervention programme. In both of these studies enhanced levels of enthusiasm and motivation were noted when children were working on computerbased tasks.

ICT offers the prospect of bridging access gaps for children with special educational needs, although not all ICT designed to assist children with special educational needs has to be 'high-tech'. Haugen (1998) points to the benefits of 'low-tech' devices such as large button-like switches to control electrical appliances and simple communication devices that give children a 'voice' by playing a recorded message when a picture is touched.

Haugen goes on to cite a number of studies in the USA which demonstrate the benefit that pre-school children with special educational needs can derive from ICT. For example, a UCLA Intervention Program demonstrated that toddlers and pre-school children with disabilities showed more enjoyment, active engagement and social play during computer activities with peers and adults than in similarly structured activities away from the computer (Howard et al, 1996). Walker and Rostron (1999) and Douglas (2001) offer examples of computer based learning experiences assisting deaf and visually impaired children respectively. However, as Douglas explains, ICT can be a double-edged sword for children with disabilities. The rapid development of mainstream technology results in improved tools (e.g. good quality speech-synthesis) but also challenges access technology to keep up.

\section{Learning with ICT}

\section{Using ICT as a pedagogical tool}

Views on whether ICT enhances or facilitates learning are polarised. Elkind (1996) points out that computer proficiency does not mean cognitive development. Healy (1998) adopts a negative stance. Arguing that use of computers is damaging to young children' s development and, therefore, to their learning she emphasises their need for human support and verbal interaction. However, a project exploring effective pedagogy using ICT in primary schools (Moseley, undated) suggested that computers can enhance teaching in three ways: presenting ideas dynamically (e.g. changing word endings, zooming along a number line); providing feedback as children work; offering the capacity to present information in easily changed forms (e.g. editing text). These 
techniques have ready parallels in pre-school settings too, for instance: adding initial letters to form a word; giving feedback to correct or incorrect answers; word processing a dictated story or annotating a drawing.

Effective use of ICT in the playroom or classroom requires new ways of thinking about computers as tools for teaching and learning. Adding a computer as another 'centre' in the room or using it for drill and practice does not maximise the opportunities that it affords for teaching and learning, as suggested by Cuban's (2001) use of the term 'a benign addition' to describe the use of computers in traditional early childhood programmes. Davis and Shade (1999) argue strongly for teachers to abandon the use of computers in classrooms for drill and practice and turn their attention to ways in which ICT can be integrated into their practice. Observations in a kindergarten led Labbo et al (2000) to conclude that a computer centre can be incorporated successfully into the patterns of playroom activities if the teacher finds ways to use the technology to meet children's learning needs. Three kinds of interactions were found to be most effective: brief targeted moments when adult and child worked together; spur-of-the-moment activities that arose from play or conversation and thematically linked activities, planned to present key concepts in a variety of ways.

The particular way in which practitioners use ICT and interact with children as they engage in ICT activities has long been a matter of concern for some writers. Haugland (1999) advocates a 'hands off' approach, suggesting that children should be allowed to experiment with the computer and that adults should only intervene when the children appear frustrated. However she adds that because the teacher is observing what the child can do he or she can expand the learner's computer experiences.

This approach is in some contrast to that advocated by other writers. As long ago as 1994 Schetz and Stremmel argued that, while the use of appropriate software is important, the role of the teacher is a greater concern. They advanced a theoretical framework of learning (derived from Vygotsky, 1978) that emphasised the role of social interaction in the learning process. In this framework the adult has a key role in scaffolding learning within the child's 'zone of proximal development'. They can recruit children for activities using the computer and maintain their interest, assist them with task completion (e.g. giving hints or directing children to the next part of the task), help children to identify why a response was incorrect, reduce children's frustration if they fail and demonstrate solutions.

Haugland's 'hands off' approach to adults supervising children using computers in the playroom is predicated on two key assumptions: that the software they are using is developmentally appropriate and, secondly, that different modes of interaction with computers are appropriate at different ages. She suggests that 3- and 4-year olds are developmentally ready to explore computers and need time to experiment and explore. Other researchers are critical of an exploratory approach to computer use that they argue leads to random-responding or mouse clicking to get some effect in the animation that is unrelated to learning, or 'window shopping' through programmes (Forman 1998, Labbo et al, 2000).

A number of researchers (Liang and Johnson, 1999; Silvern, 1998; Frost, Shin and Jacobs, 1998) have described ways in which they consider that computers can be part 
of play activities. Yelland (undated) describes technological toys that she argues can be used for interactive play, for instance, a computer game using doll characters that can be programmed with particular characteristics. While there is clearly a view among some researchers that children can use ICT, particularly computers, in a playful way the papers which describe this offer little or no evidence of the child's perspective and it is possible to argue that this playfulness is an adult interpretation of informal learning activities which may appear more structured and less playful to a child.

\section{Does ICT facilitate development?}

There is no clear evidence as to the way in which ICT facilitates young children's learning in general or in any specific curricular area. Early studies (Haugland, 1992; Fatouros, 1995) claimed that the use of ICT enhanced development across a range of areas (e.g. non-verbal skills, long term memory, problem solving, verbal skills). However, these studies have not been replicated and later studies make more modest claims for development in particular areas such as spelling. Generalised claims can still be found in print and on web sites about the positive impact on development of ICT but they lack any evidence of measured effects.

While some writers claim that using a computer can assist with fine motor development Hohmann (1998) is clear that, except for the co-ordination involved in using a mouse, computers do not support the development of motor activities or motor skills development. There are many references to ICT use facilitating communication between children, turntaking and collaborative problem solving (Clements et al, 1993, Fatouros, 1995) but despite the claims for social development (and anecdotal evidence of children sharing use of a computer, talking together and sometimes enjoying an animation together) there are few good, recent studies available to substantiate this for pre-school children in particular.

ICT offers many opportunities for children to develop their knowledge and understanding of the world. It offers opportunities to use mathematical concepts, such as sorting, matching, shapes and patterning. As pre-school children generally cannot read, only websites designed specifically for that age range are likely to be of value but the Internet is nevertheless a rich resource for practitioners. CD-ROMS can offer 'virtual' experiences such as a trip to a zoo or another country that are beyond the child's immediate environment.

The combination of drawing and art programmes with word processing and even the opportunity to add sound or music appears to offer opportunities for expressive and aesthetic development. However, Fomichova and Fomichov (2000) caution that children need to value their own creativity and to know that others recognise it too before they are exposed to computers. They argue that this will allow children to use ICT as a creative tool rather than lose their creativity to the technology.

Language development and emerging literacy is the curricular area that is most commented on in the literature on ICT use but the studies reported yield complex findings. For example, a study of the use of talking books in primary school (Lewin, 2000) suggested that the impact of technology depended on interactions between learner preferences, reading ability and the nature of the software. Nevertheless, she 
was able to conclude that electronic books can complement teaching in infant classrooms, having a positive effect on cognitive and affective outcomes. Similarly, Shilling (1997) found that the use of speech-synthesised feedback was likely to be most supportive when children already exhibited metalinguistic awareness and were beginning to recognise sound/symbol relationships, easily identified words and how words are constructed on and off the computer. Children who had not reached that stage were either unaffected by the speech-synthesised feedback or confused by it. Such evidence points to the critical role of the practitioner. As Mioduser et al (2000) concluded

Close observation of the child's performance followed by mindful pedagogical decision-making are of great importance.

Two pilot studies designed to consider the efficacy of multimedia programmes for the training of reading and spelling are reported by van Daal and Reitsma (2000). In the first study they found that independent computer practice accelerated learning in 5year olds. The second study suggested that 'reading disabled' children were engaged in less off-task behaviour during computer sessions than classroom sessions. While the claims for children's reading attainment may be open to question the results of the second study illustrate the common belief (e.g. Mioduser et al, 2000) that computer use is motivating and engaging for most children and can offer a way to break a cycle of failure to learn.

ICT may support writing for young children as well as reading or pre-reading skills. Liang and Johnson (1999) suggest that some literacy behaviour is easier with technology, arguing that it is easier to type than to write. Moxley et al (1997) studied 3- and 4-year olds using the computer in a language activity that was self-selected. The children showed steady improvement in spelling (beginning with invented spelling) and storytelling. The researchers acknowledged that they were unable to tell how much of the children's attainment is due to the use of the computer but suggested that their data make a case for moving writing into the pre-school curriculum.

\section{Conclusion}

While the debate over the potential benefits and hazards associated with computer use by young children continues without resolution policy makers, providers, practitioners and parents support the use of ICT in pre-school settings in the UK. Evidence to support the claims that ICT facilitates development may be unclear but a consensus is emerging that ICT does have a contribution to make as a way of motivating children or engaging them in a curricular area that they might otherwise reject. As such it can be a valuable addition to practitioners' repertoires (although not necessarily one that they would use routinely). It is clear however that the pedagogical imperative remains with the skilled practitioner who knows the child, how she prefers to learn, when and with whom she learns and the stage that her learning has reached. This presents a challenge for pre-school staff. In many playrooms supervising the computer or other ICT resources is only part of a practitioner's role for the day and one to which she cannot give undivided attention. Furthermore, practitioners may have limited knowledge of the possibilities of the software programmes available, lack confidence in the use of the hardware and have had little or no opportunity to 
incorporate ICT into their repertoire of pedagogical skills or develop an understanding of multi-media contexts and ways in which to nurture ICT literacy.

\section{References}

Alliance For Childhood (2000) Fool's Gold: A Critical Look at Computers in Childhood.

http://www.allianceforchildhood.net/projects/computers/computers_reports.htm

BECTA (2001) Keyboard Skills in Schools (Information sheet).

http://www.becta.org.uk/technology/infosheets/index.html

Buckingham, D. (2000) After the Death of Childhood: growing up in the age of electronic media (Oxford, Polity Press).

Clements, D.H., Nastasi, B.K. \& Swaminathan, S. (1993) Young children and computers: Crossroads and directions from research. Young Children, 48, 2, 56-64.

CoHEN, R. (1993) The use of voice synthesizer in the discovery of the written language by young children.Computers and Education, 21,1/2, pp. 25-30.

Cuban, L. (2001) Oversold and Underused: Computers in the Classroom (Cambridge, MA, Harvard University Press).

DAvis, B. C. \& SHADE, D. D. (1999) Integrating Technology Into the Early Childhood Classroom: The Case of Literacy Learning, Information Technology in Childhood Education, pp. 221-254.

Douglas, G. (2001) ICT, Education, and Visual Impairment. British Journal of Educational Technology, 32, 3, pp. 353-364.

ElKIND, D. (1996) Young Children and Technology: A cautionary note. Young Children, 51,6, pp. 22-23.

Elliot, A. \& HALl, N. (1997) The Impact of Self-Regulatory Teaching Strategies on "At-Risk" Preschoolers' Mathematical Learning in a Computer-Mediated Environment. Journal of Computing in Childhood Education, 8, 2/3, pp. 187-198.

FAtOuRos, C. (1995) Young children using computers: Planning appropriate learning experiences. Australian Journal of Early Childhood, 20, 2, pp. 1-6.

Fomichova, O. \& Fomichov V. (2000) Computers and the thought-producing self of the young child. British Journal of Educational Technology, 31 (3) pp.213-220.

Forman, G. (1998). Constructive Play. In D. Fromberg \& D Bergen (Eds) Play from birth to twelve and beyond: Contexts, perspectives, and meaning, pp. 392-400, (New York, Garland). 
Frost, J, Shin, D. \& JACOBS, P. (1998) Physical environments and children's play. In O. Saracho \& B. Spodek (Eds) Multiple perspectives on play in early childhood education, pp. 255-294 (Albany NY, SUNY Press).

Haugen, K. (1998) Using Technology to Enhance Early Learning Experiences. Child Care Information Exchange, 9/98, pp. 47-55.

HAUGLAND. S. (1992) The effect of computer software on preschool children's developmental gains, Journal of Computing in Childhood Education, 3, 1, pp. 15 30 .

Haugland, S. (1999) What Role Should Technology Play in Young Children's Learning? Young Children, 54, 6, pp. 26 - 31.

Haugland, S. (2000) Early Childhood Classrooms in the 21st Century: Using Computers to Maximise Learning. Young Children, 55,1, pp.12 - 8.

Haugland, S \& Wright, J. (1997) Young Children and Technology (Boston, MA, Allyn \& Bacon), Developmental scale also available at http://www.childrenandcomputers.com/Evaluations/software/softwarescale.htm

Healy, J. (1998) Failure to Connect: How Computers Affect Our Children's Minds - for Better or Worse (New York, Simon \& Schuster).

Hohmann, C. (1998) Evaluating and Selecting Software for Children. Child Care Information Exchange, 9, 98, pp. 60-62.

Howard, J., Greyrose, E., Kehr, K., Espinosa, M. And Beckwith, L. (1996) Teacher-facilitated micro-computer activities: Enhancing social play and affect in young children with disabilities, Journal of Special Education Technology, Spring, xiii, 1.

Labbo, L. D., Sprague, L., Montero, M.K. \& Font, G. (2000) Connecting a computer center to themes, literature and kindergarteners' literacy needs, Reading Online, 4,1, http://www.readingonline.org/electronic/labbo/

LEWIN, C. (2000) Exploring the effects of talking books software in UK primary classrooms. Journal of Research in Reading, 23, 2, pp. 149-157.

Liang, P-H \& Johnson, J. (1999) Using Computers to Enhance Early Literacy Through Play, Computers in the Schools, 15, 1, pp. 55-63.

MARsh, J \& ThOMPSON, P. (2001) Parental involvement in literacy development: using media texts, Journal of Research in Reading, 24, 3, pp.266-278.

Mioduser, D. TUR-KASPA, H. \& LeITNER, I. (2000). The learning value of computerbased instruction of early reading skills. Journal of Computer Assisted Learning, 16, pp. $54-63$. 
Moseley, D., Higgins, S. et al (undated) Ways forward with ICT: Effective Pedagogy using Information and Communications Technology in Literacy and Numeracy in Primary Schools, A Report to the TTA. Newcastle University.

Moxely, R. A., Warash, B., Coffman, G., Brinton, K. \& ConCANnON K. R. (1997) Writing Development Using Computers in a Class of Three-Year-Olds. Journal of Computing in Childhood Education, 8, 2/3, pp.133-164.

NATiOnal Association For The EduCATION OF Young CHILDREN (1996)

Technology and Young Children - Ages 3 through 8

http://www.naeyc.org/resources/position_statements/positions_intro.htm

NATIONAL CURRICULUM FOR ENGLAND (2000)

http://www.nc.uk.net/servlets/NCFrame?subject=ICT\&KeyStage $=1$

National School Boards Foundation (2000) Safe and Smart. Research and Guidelines for Children's Use of the Internet.

http://www.nsbf.org/safe-smart/index.html

Nicholson, R. I., FAwcett, A. J. \& Nicholson, M. K. (2000) Evaluation of a computer-based reading intervention in infant and junior schools, Journal of Research in Reading, 23, 2, pp. 194-209.

Plowman, L. (1998) Reading multimedia texts, Language Matters, Spring, pp. 1922.

Plowman, L., Mateer, J. \& Leakey, A. (forthcoming, 2002) Connecting schools, libraries and community education centres with ICT. Interchange No ?

http://www.scotland.gov.uk/edru/edrupub.asp

Resnick, M. Et Al. (1998). Digital Manipulatives: New Toys to Think With, Proc. CHI 98 (ACM conference on Human Factors in Computing Systems), Los Angeles. pp. 281-287.

SchetZ, K. F. \& StRemMel, A.J. (1994) Teacher-assisted Computer Implementation: a Vygotskian Perspective, Early Education and Review, 5,1, pp. 18-26.

Scottish Consultative Council ON The Curriculum (SCCC) (1999) A Curriculum Framework for Children 3 to 5, Dundee, Scottish Consultative Council on the Curriculum.

SElwyn, N. \& Bullon, K. (2000) Primary school children's use of ICT, British Journal of Educational Technology, 31, 4. pp. 321-332.

Shade, D. D. (1996) Are You Ready to Teach Young Children in the 21st Century? Early Childhood Education Journal, 24, 1, pp. 43-44.

Siraj-Blatchford, J. \& Siraj-Blatchford, I. (2001) Kidsmart: The Phase 1 UK Evaluation 2000-2001, Final Project Report.

http://www.ioe.ac.uk/cdl/datec/finawebCopy.pdf 
ShILLING, W.A. (1997) Young Children Using Computers to Make Discoveries About Written Language. Early Childhood Education Journal, 24, 4, pp. 253-259.

SILVERN, S. (1998) Educational implications of play with computers. In D. Fromberg \& D Bergen (Eds) Play from birth to twelve and beyond: Contexts, perspectives, and meaning, pp. 392-400 (New York, Garland).

Stephen, C., Brown. S., Cope, P. \& Waterhouse, S. (2001). All-day Provision For 3-and 4-Year Olds: The experiences of children, parents, providers and practitioners. Stirling, University of Stirling.

Strommen, E. \&. AlexAnder, K. (1999) Emotional Interfaces for Interactive Aardvarks: Designing Affect into Social Interfaces for Children. Proc. CHI '99 (ACM conference on Human Factors in Computing Systems). pp.528-535.

Talley, S., Lancy, D. F., \& LeE, T.R. (1997) Children, Storybooks and Computers, Reading Horizons, 38,2,pp.116-28.

TURBILL. J, (2001) A researcher goes to school: Using technology in the Kindergarten literacy curriculum, Journal of Early Childhood Literacy, 1, 3, pp. 255-279.

Turow, J. \& NiR, L. (2000) The Internet and the Family 2000: the view from parents, the view from kids, Report 33, Annenberg Public Policy Center, University of Pennsylvania.

Van DAal, V. \& Reitsma, P. (2000) Computer-Assisted Learning To Read and Spell: Results from Two Pilot Studies. Journal of Research in Reading, 23, 2, pp. 181-93.

VyGOTSKY, L. (1978) Mind in society: The development of higher psychological processes. Cambridge, MA., Harvard University Press.

WALKER, J. \& Rostron, A. (1999) CAL and acoustic environments for deaf children. Journal of Computer Assisted Learning, 15, pp. 85-86.

Williams, D., Coles, L., Wilson, K., Richardson, A. \& Tuson, J. (2000) Teachers and ICT: current use and future needs, British Journal of Educational technology, 31, 4, pp. 307-320.

Wright, C. (2001) Children and Technology: Issues, Challenges, and Opportunities. Childhood Education, 78, 1, pp. 37-41.

YellaND, N. (1999) Reconceptualising schooling with technology for the $21^{\text {st }}$ century, Information Technology in Childhood Education Annual, pp. 39-59.

YelLAND, N. (undated) New ways of playing: Digital toys for the new millenium. Australian Early Childhood Association, Darwin Conference Papers. http://www.aeca.org.au/darconfyell.html 
Yost, N. (1998) Computers, kids and crayons: A comparative study of one kindergarten's emergent literacy behaviours, Unpublished doctoral dissertation. Department of Curriculum and Instruction, Pennsylvania State University, University Park, PA. 